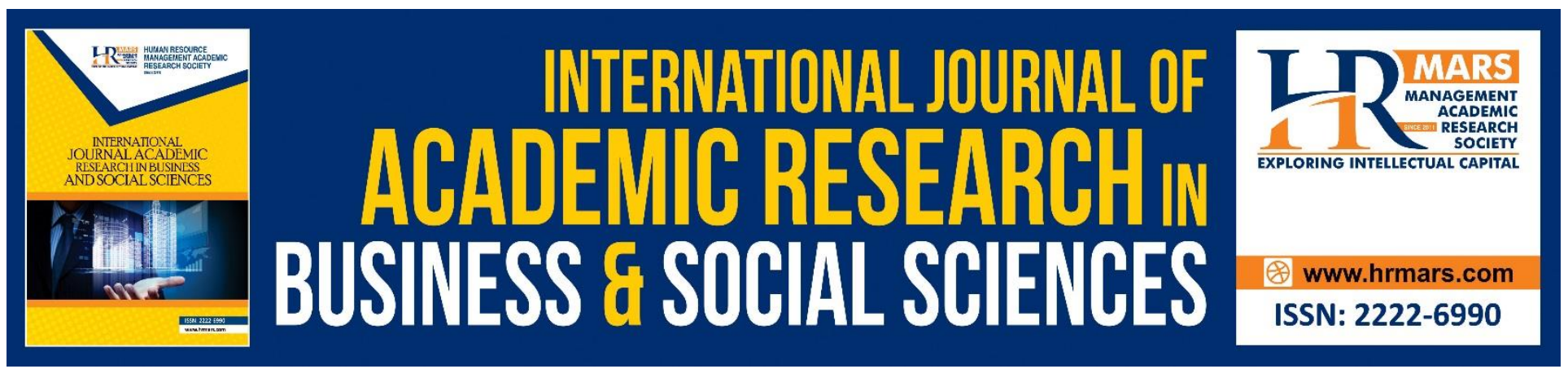

\title{
Accessibility Analysis of Interactive Kiosk in National Music Museum
}

Mohd Nasiruddin Abdul Aziz, Nor Suzila Lop, Izatul Farrita Mohd Kamar, Lizawati Abdullah, Norizan Mt Akhir

To Link this Article: http://dx.doi.org/10.6007/IJARBSS/v10-i9/7983 DOI:10.6007/IJARBSS/v10-i9/7983

Received: 08 June 2020, Revised: 11 July 2020, Accepted: 15 August 2020

Published Online: 28 Septmeber 2020

In-Text Citation: (Abdul Aziz, et. al., 2020)

To Cite this Article: Abdul Aziz, M. N., Lop, N. S., Kamar, I. F. M., Abdullah, L., \& Akhir, N. M. (2020). Accessibility Analysis of Interactive Kiosk in National Music Museum. International Journal of Academic Research in Business and Social Sciences. 10(9), 1033-1046.

Copyright: (C) 2020 The Author(s)

Published by Human Resource Management Academic Research Society (www.hrmars.com)

This article is published under the Creative Commons Attribution (CC BY 4.0) license. Anyone may reproduce, distribute, translate and create derivative works of this article (for both commercial and non-commercial purposes), subject to full attribution to the original publication and authors. The full terms of this license may be seen

at: http://creativecommons.org/licences/by/4.0/legalcode

Vol. 10, No. 9, 2020, Pg. 1033 - 1046

http://hrmars.com/index.php/pages/detail/IJARBSS

JOURNAL HOMEPAGE

Full Terms \& Conditions of access and use can be found at http://hrmars.com/index.php/pages/detail/publication-ethics 


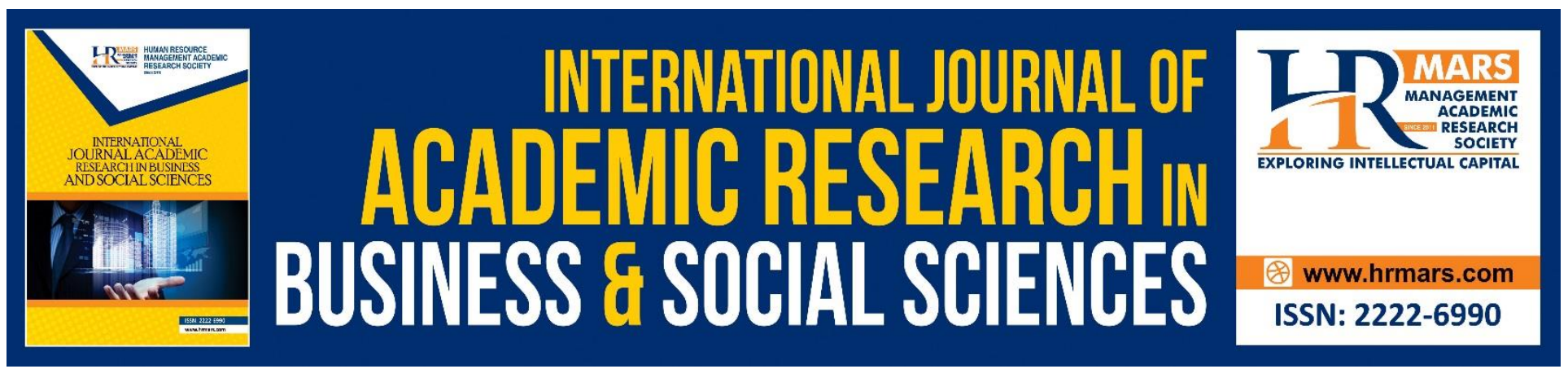

\title{
Accessibility Analysis of Interactive Kiosk in National Music Museum
}

\author{
${ }^{1}$ Mohd Nasiruddin Abdul Aziz, ${ }^{2}$ Nor Suzila Lop, ${ }^{3}$ zzatul Farrita Mohd \\ Kamar, ${ }^{4}$ Lizawati Abdullah, ${ }^{5}$ Norizan Mt Akhir \\ ${ }^{1}$ Faculty of Art and Design, Universiti Teknologi MARA, Perak Branch, 32610 Seri Iskandar, Perak, \\ Malaysia, 2,3,4,5 Faculty of Architecture, Planning, and Surveying, Universiti Teknologi MARA, Perak \\ Branch, 32610 Seri Iskandar, Perak, Malaysia
}

\begin{abstract}
The interactive kiosk has been implemented in Malaysian museums as an active and supportive learning approach with high investment costs. However, the benefits of the investment on the digital information system is dependent on the accessibility of the kiosk itself. Thus, this study aims to analyse the accessibility of the interactive kiosk in Malaysian museums in terms of the directional flows, locations, specifications, structure of the systems, user interface designs and language of the systems. The data collected from the site visit observations and interviews was analysed qualitatively. These was later supported by the literature review. This study found that the interactive kiosk at the National Music Museum is accessible for normal visitors. However, certain physical criteria are not convenient for wheelchair users. An improvement on the physical accessibility is recommended to ensure that the interactive kiosk will be beneficial to all types of visitors, especially for the disabled. Apart from that, the familiarity of the languages used is also crucial in engaging the foreign visitors into using the interactive kiosks in Malaysian museums in the future.
\end{abstract}

Keywords: Malaysia, Museum, Learning, Interactive, Kiosk.

\section{Introduction}

The Industrial Revolution 4.0 agenda has emphasized on the importance of digital approach for formal and informal educational institutions (Robandi, Kurniati, \& Puspita Sari, 2019). Realizing the importance of interactive technology for museums, The Minister of Culture, Arts and Heritage of Malaysia has challenged the museums in Malaysia to comply and be at par, if not better with other museums in the world (Saidin, Alwi, \& Shaari, 2018). Responding the challenge, the idea of using interactive kiosk has been brought into Malaysian museums which offers different set of applications such as games, multimedia presentations and interactive books (Nizar \& Rahmat, 2018). The interactive kiosk has taken place in museums as an active and supportive learning tools to enhance the visitors' learning experiences.

The implementation of the interactive kiosk as an information system is expensive and has relatively low success rate (Legris, Ingham, \& Collerette, 2003). Based on the statistical report in 2018, 
INTERNATIONAL JOURNAL OF ACADEMIC RESEARCH IN BUSINESS AND SOCIAL SCIENCES Vol. 10, No. 9, 2020, E-ISSN: 2222-6990 @ 2020 HRMARS

the Department of Malaysian Museums has spent more than 14 million Ringgit Malaysia on services and supplies in maintenance and development of the 21 federal government museums (Jabatan Muzium Malaysia, 2018). The total cost also includes the cost of providing several interactive kiosks to the selected museums. It is important to highlight that the benefits of the investments by the government on the interactive kiosk are dependent on the acceptance of the new technology by visitors of the museums (Kim \& Qu, 2014; Wang \& Shih, 2009). Museums in Malaysia have faced many challenges in changing the perception that museums are a dull entity and at the same time trying to maintain their financial performance (Saidin et al., 2018). Public's perception of the museums is important to ensure that the support and funding from the government are continued (Taha, 2008).

Not all the visitors are interested to use the digital media elements in museum exhibitions (Burmistrov, 2015). Falk and Dierking (2013) have mentioned that people will spend time working with multimedia only if they want to learn more and are interested in the topic. The flashy, expensive or decorative media technology does not guarantee that the visitor will use the interactive technology at the museums. Contras to the recent studies, the design elements of an interactive application at the museums are capable in enhancing the intention of the visitors to use the interactive applications and promote engagement effectively (Jung \& Yim, 2018; Kamaruddin, 2019). According to Technology Acceptance Model, ease of use and usefulness are the major believed factors in technology adoption. In order to ensure the investment by the government on the interactive kiosk is worthwhile for the museums' development, an evaluation and analysis of the interactive kiosk's accessibility in Malaysian museums are needed.

\section{Museums in Malaysia}

Based on previous research, the total number of museums in Malaysia are inconclusive. Ahmad, Abbas, Yusof, and Taib (2013) mentioned that there are more than 150 museums in Malaysia. On the other hand, according to statistical data by Salleh (2015), the total number of museums in Malaysia is 132, including the 22 museums under the Federal Government. However, the latest data from the Department of Malaysian Museums (Jabatan Muzium Malaysia, 2018) shows that there are only 21 museums under the Federal Government. The Nature Museum in Putrajaya was closed on February 2017. However, the number remained because the National Music Museum was added in the report in 2018. Taking into account the latest data and supported by the statistical survey from Salleh (2015), this research assumes that the total number of museums in Malaysia is 131 (Figure 1).

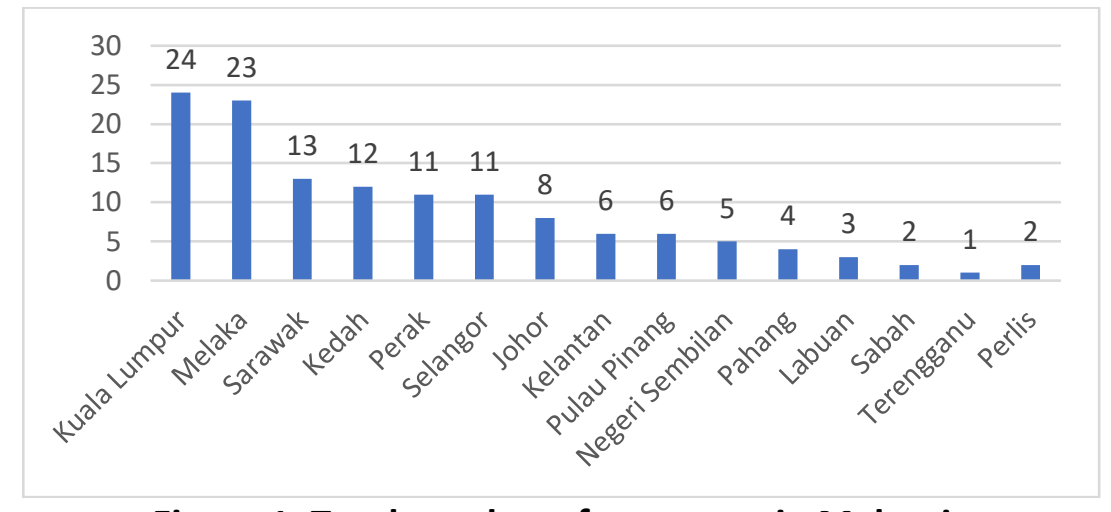

Figure 1. Total number of museums in Malaysia 
INTERNATIONAL JOURNAL OF ACADEMIC RESEARCH IN BUSINESS AND SOCIAL SCIENCES Vol. 10, No. 9, 2020, E-ISSN: 2222-6990 @ 2020 HRMARS

\section{The Administration of The Museums}

The administrations of museums in Malaysia have been categorised into five categories (Salleh, 2015). Table 1 shows the five categories which are the Federal Government with 21 museums (16.5\%), State Governments with 65 museums (49.5\%), Government Agencies with 31 museums (24\%), Government Linked Companies with 2 museums (1.5\%) and Private ownership with 12 museums (9\%).

Table 1. The Administrations of the Museums

\begin{tabular}{llll}
\hline No. & The Administration & Museums & Percentage \\
\hline 1 & Federal Government & 21 & $16 \%$ \\
2 & State Governments & 65 & $49.5 \%$ \\
3 & Government Agencies & 31 & $24 \%$ \\
4 & Government Linked Companies & 2 & 1.5 \\
5 & Private ownership & 12 & $9 \%$ \\
\hline Total Museums in Malaysia & 131 & $100 \%$ \\
\hline
\end{tabular}

This research focuses on museums under the Federal Government because of the generous funding from the government and their responsibilities as a role model for other museums in Malaysia (Taha, 2008). There are 21 museums (16\%) under the Federal Government administration and it is named the Department of Malaysian Museums (Error! Reference source not found.). There are 6 Federal Government museums located in Wilayah Persekutuan, Kuala Lumpur, which is the highest number of museums with the highest number of visitors in 2018. 
INTERNATIONAL JOURNAL OF ACADEMIC RESEARCH IN BUSINESS AND SOCIAL SCIENCES Vol. 10, No. 9, 2020, E-ISSN: 2222-6990 @ 2020 HRMARS

Table 2. The numbers of visitors in $\mathbf{2 0 1 8}$

\begin{tabular}{llll}
\hline No. & List of the Museums & State & Visitors in 2018 \\
\hline 1 & National Museum & W.P Kuala Lumpur & 739,909 \\
2 & Malay World Ethnology Museum & W.P Kuala Lumpur & 80,812 \\
3 & Orang Asli Crafts Museum & W.P Kuala Lumpur & 85,284 \\
4 & National Textile Museum & W.P Kuala Lumpur & 79,232 \\
5 & Royal Museum & W.P Kuala Lumpur & 152,282 \\
6 & National Music Museum & W.P Kuala Lumpur & 22573 \\
7 & National Automobile Museum & Selangor & 105,837 \\
8 & Labuan Museum & W.P Labuan & 79,486 \\
9 & Labuan Marine Museum & W.P Labuan & 159,101 \\
10 & Chimney Museum & W.P Labuan & 66,961 \\
& Lembah Bujang Archaeological & & 186,846 \\
11 & Museum & Kedah & \\
12 & Kota Kuala Kedah Museum & Kedah & 277018 \\
13 & Galeria Perdana & Kedah & 90,956 \\
14 & Perak Museum & Perak & 233,186 \\
15 & Matang Museum & Perak & 60,758 \\
16 & Sungai Lembing Museum & Pahang & 82,507 \\
17 & Custom Museum & Negeri Sembilan & 93,793 \\
18 & Lukut Museum & Negeri Sembilan & 39,013 \\
19 & Malaysia Architectural Museum & Melaka & 74,485 \\
20 & Kota Johor Lama Museum & Johor & 39,078 \\
21 & Muzium Kota Kayang & Perlis & 61,102 \\
\hline
\end{tabular}

\section{The Interactive Kiosk in The Museums}

The researchers have conducted site-visit observations on the six Federal Government museums to evaluate the existing interactive kiosks in the exhibition hall areas. As shown in Table 3, only 3 museums have been installed with the interactive kiosk for visitors' use which are the National Music Museum, Royal Museum, and National Museum. However, the interactive kiosk in the Royal Museum is strictly confidential and is restricted for any research proposes, whilst the interactive kiosks at the National Museum malfunctioned and were under maintenance.

Table 3. The conditions of interactive kiosk

\begin{tabular}{llll}
\hline No. & List of Museums & Interactive Kiosk & Conditions \\
\hline 1 & $\begin{array}{l}\text { National Museum } \\
\text { Malay World Ethnology }\end{array}$ & 4 & $\begin{array}{l}\text { Under } \\
\text { maintenance }\end{array}$ \\
2 & Museum & 0 & Not Available \\
3 & Orang Asli Crafts Museum & 0 & Not Available \\
4 & National Textile Museum & 0 & Not Available \\
& & 1 & strictly \\
5 & Royal Museum & & confidential \\
6 & National Music Museum & 5 & Good \\
\hline
\end{tabular}




\section{Methodology}

The National Music Museum was selected for this research because of the highest level of administration, is located in the Wilayah Persekutuan, Kuala Lumpur which has the highest number of museums with the highest number of total visitors and due to the conditions of the existing interactive kiosks which are good. There is no specific recorded documentation that can be gathered from the museum administration about the implementation of the interactive kiosks. In order to get a clearer picture, the researchers have interviewed the director of the National Music Museum and observed the interactive kiosks in the museum directly. The collected data from the observations and interviews were qualitatively analysed and supported by the literature review.

Based on the measurement items from M-Dimensions Framework (Gonçalves, Campos, \& Sousa, 2012) and public information kiosk systems guidelines (Maguire, 1999), six elements were chosen to be analysed which are the directional flows, locations, specifications, structure of the systems, user interface designs and languages. M-Dimensions Framework was chosen because it is the most comprehensive set of evaluation criteria for interactive installation in the museum and was recognized by the expert in human-computer interaction (Burmistrov, 2015). Public information kiosk systems' guidelines by Maguire (1999) was chosen because of the comprehensiveness and it was cited as a reference by numerous research on interactive kiosk until today (Dugar, 2018; GómezCarmona, Casado-Mansilla, \& López-de-Ipina, 2018; Luse, Vidrio-Baron, Mennecke, \& Townsend, 2008).

\section{Results and Discussions}

The researchers have analysed and evaluated the accessibility of the interactive kiosks in terms of the directional flows, locations, specifications, structure of the systems, user interface designs, and languages. Each of the result has been described and supported by the literature review as follows.

\section{The Directional Flow}

All the kiosks need a careful positioning according to the visitors' flows in the museum with a systematic planning and evaluation (Economou, 2008; Gonçalves et al., 2012). The visitors will feel uncomfortable and their interaction with the kiosks will be shorter if the kiosks are placed at a busy corridor (Falk \& Dierking, 2013). Based on the observation at the site visit, the researchers have depicted the directional flows of the visitors in the museum as shown in Fig. 2. The visitors are provided with a big panel of the National Music Museum setting in front of the entrance door that serves an introduction to their visit. 


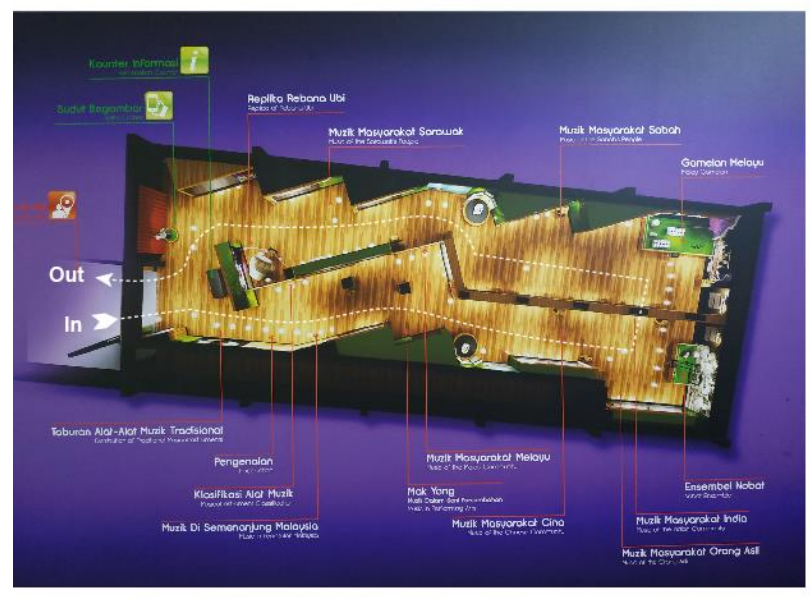

Figure 0. The Directional Flow in the National Music Museum

The visitors are required to fill in the attendance book at the information counter once they have arrived. The exhibition will start with the information on the distribution of the traditional musical instruments, followed by introduction, musical instrument classification, music in peninsular Malaysia, music in performing arts (Mak Yong), music of the Malay community, music of the Chinese community, music of the Orang Asli, music of the Indian community, Nobat ensemble, Malay Gamelan, music of the Sabah's people, music of the Sarawak's people, replica of Rebana Ubi and finally, a selfie corner.

\section{The Location of the Interactive Kiosk}

The location of the interactive kiosks is one of the key factors in determining the success of the implementation of the kiosks in the museums (Burmistrov, 2015). There are five interactive kiosks that can be found in the National Music Museum as shown in Fig. 3. The location is along the walking flow of the museum setting and it is located 2 feet away from the related displayed items.

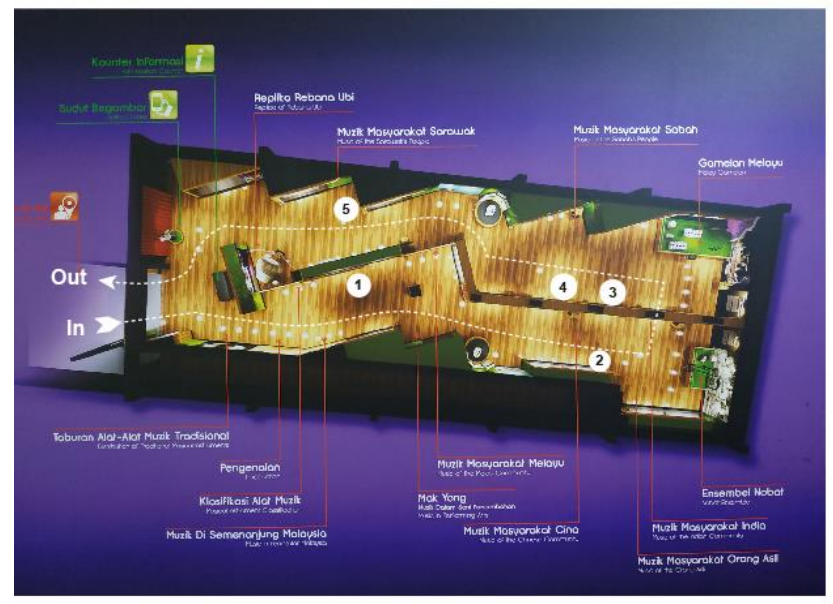

Figure 3. Location of the Interactive Kiosk in the National Music Museum

Gillette, O'Brien, and Bullard (2011) have emphasized that kiosks in museums should be approachable and reachable by all the museum visitors because the meaningful and relevant 
experience will be generated when they feel that they are in control. In line with that statement, the interactive kiosks in the National Music Museum are approachable to the visitors because they are located at the left and right side along the walking areas. Each of the kiosk is installed with different kinds of information related to the nearest display items. Kiosk 1 provides information on Malay musical instruments, kiosk 2 on Orang Asli's musical instruments, kiosk 3 on Indian musical instruments, kiosk 4 on Chinese musical instruments and kiosk 5 on Sabah and Sarawak musical instruments.

\section{Specification of the Kiosks}

Previous research have found that the use of touchscreen technology can cause body discomfort and physical loads if not designed carefully (Kang \& Shin, 2014; Parikh \& Esposito, 2012; Shin \& Zhu, 2011). The height of the kiosks, screen angle, screen size and the screen distance play an important role on the success rate of the interactive kiosks in the museums. All the details of the kiosks' specifications in the National Music Museum have been measured as shown in Fig. 4.

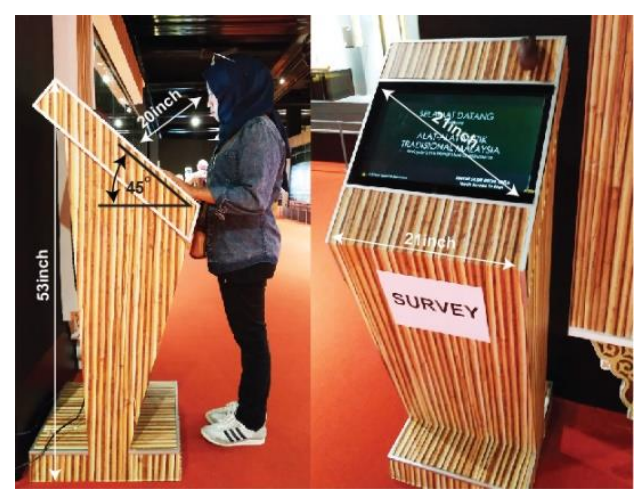

Figure 4. Specification of the Interactive Kiosks in the National Music Museum

The interactive kiosks in the National Music Museum have been installed with a touchscreen technology so that they would be more accessible to the users. The visitors can also interact with the kiosk systems by using a mouse which is provided as an optional device if the touchscreen is not working properly. Touchscreen is important for the interactive kiosks because they provide a better visualization of the interactions (Burmistrov, 2015; Heath, Luff, Lehn, Hindmarsh, \& Cleverly, 2002), a flexible way of presenting a limited range of commands, and the screen button is easier to use rather than the traditional keyboard (Maguire, 1999). However, the screen needs to be cleaned regularly because the constant using will make it dirty and less efficient.

A larger screen will help the users to see the information clearly in the user's interface display. The kiosk uses a 21inch screen to display the interface and it is positively aligned with the recommendation made by a past study that stated that the interfaces should be no less than a 17 inch screen for systems used in public areas (Little, Briggs, \& Coventry, 2005).

The degree of the screen angle is important to ensure the visitors are comfortable when using the interactive kiosks for a long period. Typically, visitors spend less than 20 minutes on certain museum exhibitions depending on the topic and size (Serrell, 1997). However, Kang and Shin (2014) found that if the touchscreen is used for a long period of up to 15 minutes with continues work, it will cause musculoskeletal discomfort or psychology effect to the users. The screen angle in the National Music Museum is tilted 30 to 45 degrees (Fig. 4) and is comfortable enough for the users as 
INTERNATIONAL JOURNAL OF ACADEMIC RESEARCH IN BUSINESS AND SOCIAL SCIENCES Vol. 10, No. 9, 2020, E-ISSN: 2222-6990 @ 2020 HRMARS

suggested by Sears (1991) and Maguire (1999). It was reported in the literature that the vertical screen display can cause a feeling of heaviness in the upper limbs which is also known as "gorilla arm", whilst the horizontal screen display can cause neck fatigue (Parikh \& Esposito, 2012; Shin \& Zhu, 2011).

The height of the kiosk is 53 inches and it is comfortable for standing adult users with 20inch distance between the face and the 21 inch screen display. As recommended by previous researchers, the screen display should be near eye level to minimise biomechanical load on the neck (Shin \& Zhu, 2011). However, the kiosk is not convenient for wheelchair users. As recommended by Gill (1997), the maximum height of the kiosk system for standing and wheelchair users should not exceed $1.2 \mathrm{~m}$ (47.2 inches) and the lowest height should not be less than $0.7 \mathrm{~m}$ ( 27.5 inches) with clear area of $1.5 \mathrm{~m}$ (59inches) radius round the kiosk terminal.

\section{Structure of the Kiosk System}

The National Music Museum provides a simple and same structure approach for all the five kiosks systems to facilitate the visitors as the first-time users. The researcher draws the structure of the kiosk system in Figure 5 for a clear picture on how it works. There are only three layers in the kiosk system with non-linear navigation to give more control over what the visitors are interested to pursue. As mentioned by Thong, Hong, and Tam, (2002) a smaller number of steps is better as compared to a deep structure because it enables users to reach their final inquiry results quickly with less cognitive effort to keep track of their searching paths.

Layer 1 is the home page for the introduction to attract the visitors' attention to use the system. There is a clear instruction on the page and the visitors just need to touch anywhere on the screen to start interacting and using the kiosks. The system will be auto reset to the home page after one minute if no input is made. As recommended by Maguire (1999), the auto-reset system is important for a public information kiosk systems to ensure that the system is ready for the next user after the system is abandoned in the middle of a dialogue by one user. However, the auto-reset cannot be too quick because it will be annoying and frustrating to the users if the system reset itself when the users are deciding what step to choose next. 


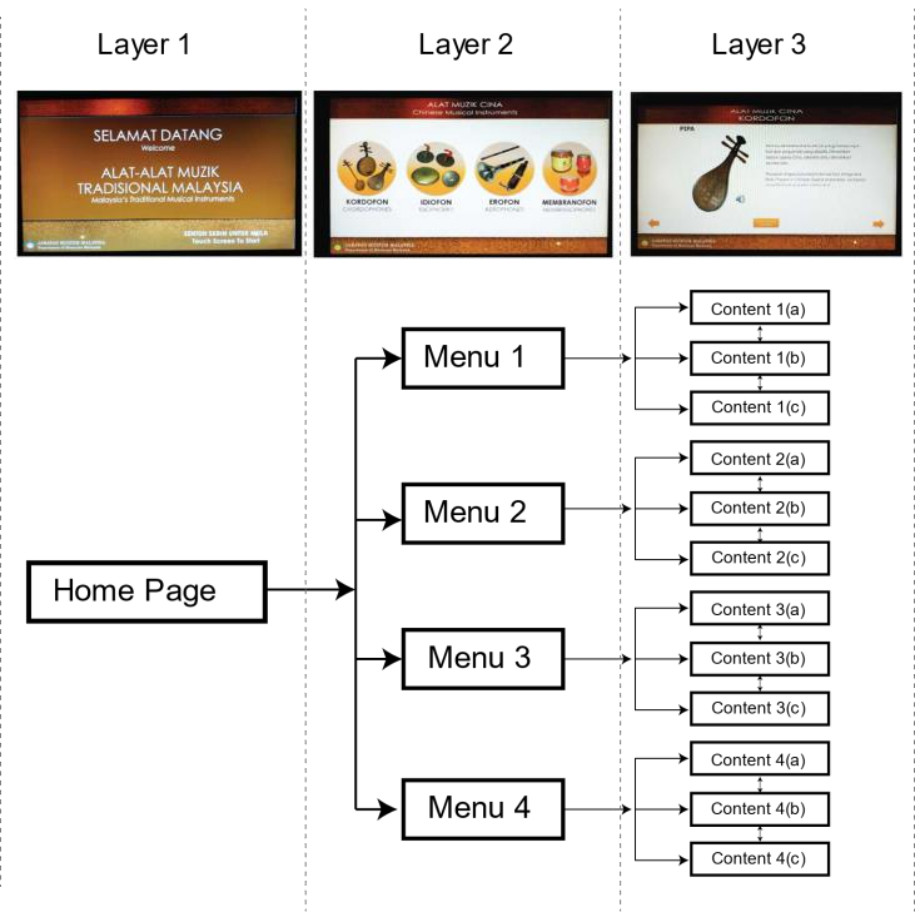

Figure 5. Structure of the Kiosk System

Layer 2 is the menu page of the system. The user is free to choose what they want to know from the options given in layer 2 because of the non-linear system. The menu options for each kiosk depends on the related content with the nearest display: Kiosk 1 on Malay musical instruments, kiosk 2 on Orang Asli musical instruments, kiosk 3 on Indian musical instruments, kiosk 4 on Chinese musical instruments and kiosk 5 on Sabah and Sarawak musical instruments.

Layer 3 is the detail information pages based on the user's selection from the page in layer 2. The user can get the information by reading the text, looking the images and listening to the sample audio provided. A button is provided for the next instruments in the same group of menu selection or back to the layer 2 to change the groups of the instruments.

\section{User Interface Designs}

The interactive kiosk in the National Music Museum has combined all the important elements such as text, audio, visual images, objects and experiences in the interface designs for an exhibition as suggested by Kamaruddin (2019) (Fig. 6). Similar to the Horniman Museum in London, the visitors are able to find out more about musical instruments through texts, graphic displays and by listening to the audio made by more than one thousand musical instruments in the interactive kiosk displays (Economou, 2008). 


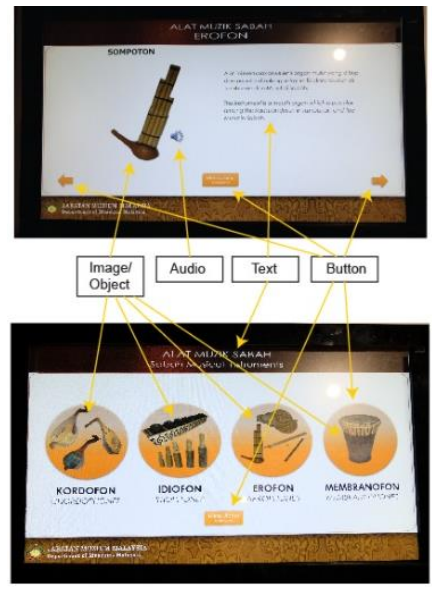

Figure 6. Sample of the User Interface Designs

The designers have used short texts and simple languages to present the information. In this digital age, most of the new generations prefer to learn using visual and audio rather than texts (Prensky, 2001a, 2001b; Zenios \& loannou, 2018). The readability of the texts is high because the designers have used sans-serif typefaces with contrasting colours for all the menus and information in the interface designs. Based on the eye-tracking studies of the onscreen typography, the san-serif font has been proved to be effectively in increasing the speed of reading and reduce the backward movement on the screen rather than the serif font (Josephson, 2008).

The layout design is consistent for all the kiosks in the National Music Museum. The same colour, design patterns, layout arrangements, icon for buttons and typefaces have been applied to all the interface designs to ensure the visitors are familiar with the system functions and will continue to use the next kiosk for different topics.

\section{Languages}

All the menus and information texts of the kiosks in the National Music Museum are provided in dual languages: Malay language as the national language, and English language as the international language (Refer Figure ). The design is set purposely for the various kinds of visitors from local to international tourists. A familiar language becomes the top priority in the accessibility of the public terminal guidelines as proposed by the Irish National Disability Authority (Burmistrov, 2015). This approach is also in line with the recommendation from Burmistrov (2015) where the user interface for kiosk needs to have useful information and understandable through visitor's language.

\section{Conclusions}

The evaluation and analysis on the interactive kiosk in the National Music Museum have found that the existing directional flows, locations, specifications, structure of the systems, user interface designs and languages of the interactive kiosk are easily accessible for normal visitors as discussed and recommended by the previous studies. However, certain physical criteria for height and clear area around the kiosk terminal are not convenient for wheelchair users. This study suggests that the Department of Malaysian Museums should to improve the physical accessibility following the international standard to ensure the investment on the interactive kiosk is beneficial to all types of visitors, especially for the disabled visitors. Apart from that, the Department of Malaysian Museums should also consider providing the texts in various other languages (besides Malay language and 
INTERNATIONAL JOURNAL OF ACADEMIC RESEARCH IN BUSINESS AND SOCIAL SCIENCES Vol. 10, No. 9, 2020, E-ISSN: 2222-6990 @ 2020 HRMARS

English) depending on the nationalities of visitors who travel frequently to Malaysia so that they will be attracted to visit the museums because the interactive kiosks are equipped with the languages familiar to them.

\section{Acknowledgement}

Special thanks goes to the Director of National Music Museum, Department of Malaysian Museums, Malaysia Ministry of Higher Education, Universiti Teknologi MARA (UiTM) Perak Branch, Faculty of Art and Design and all those who have contributed to the success of this research project.

\section{Corresponding Author}

Mohd Nasiruddin Bin Abdul Aziz

Faculty of Art \& Design, Universiti Teknologi MARA, Perak Branch, 32610 Seri Iskandar, Perak, Malaysia

Email: mohdn571@uitm.edu.my

\section{References}

Burmistrov, I. (2015). Touchscreen Kiosks in Museums. https://doi.org/10.13140/RG.2.1.4521.0087

Dugar, D. D. (2018). Public Self Service Technology ( SST ): Designing for Trust Factors enhancing user's trust towards a public. KTH Royal Institute of Technology.

Economou, M. (2008). A World of Interactive Exhibits. Museum Management and Curatorship, 17(2)(May), 173-187.

Falk, J. H., \& Dierking, L. D. (2013). The Museum Experience Revisited. California: Left Coast Press.

Gillette, E., O’Brien, H. L., \& Bullard, J. (2011). Exploring technology through the design lens: A case study of an interactive museum technology. ACM International Conference Proceeding Series, 583-590. https://doi.org/10.1145/1940761.1940840

Gómez-Carmona, O., Casado-Mansilla, D., \& López-de-Ipina, D. (2018). Multifunctional Interactive Furniture for Smart Cities. Proceedings, 2(19), 1212. https://doi.org/10.3390/proceedings2191212

Gonçalves, L., Campos, P., \& Sousa, M. (2012). M-dimensions: A Framework for Evaluating and Comparing Interactive Installations in Museums. Proceedings of the 7th Nordic Conference on Human-Computer Interaction Making Sense Through Design - NordiCHI '12, (October 2012), 59. https://doi.org/10.1145/2399016.2399027

Heath, C., Luff, P., Lehn, D. V., Hindmarsh, J., \& Cleverly, J. (2002). Crafting participation: Designing ecologies, configuring experience. Visual Communication, 1(1), 9-33. https://doi.org/10.1177/147035720200100102

Jabatan Muzium Malaysia. (2018). Laporan Tahunan Jabatan Muzium Negara. Kuala Lumpur. Josephson, S. (2008). Keeping your readers' eyes on the screen: An eye-tracking study comparing sans serif and serif typefaces. Visual Communication Quarterly, 15(1-2), 67-79. https://doi.org/10.1080/15551390801914595

Jung, W., \& Yim, H. R. (2018). An exploratory study of the interface design factors affecting the user intention to use mobile applications. International Journal of Advanced Science and Technology, 119, 103-110. https://doi.org/10.14257/ijast.2018.119.09

Kamaruddin, N. (2019). Understanding of Basic Design Process and Techniques for Effective Museum Exhibition Design. VI(Vi), 98-101. 
INTERNATIONAL JOURNAL OF ACADEMIC RESEARCH IN BUSINESS AND SOCIAL SCIENCES Vol. 10, No. 9, 2020, E-ISSN: 2222-6990 @ 2020 HRMARS

Kang, H., \& Shin, G. (2014). Hand usage pattern and upper body discomfort of desktop touchscreen users. Ergonomics, 57(9), 1397-1404. https://doi.org/10.1080/00140139.2014.924574

Kim, M., \& Qu, H. (2014). Travelers' behavioral intention toward hotel self-service kiosks usage. International Journal of Contemporary Hospitality Management, 26(2), 225-245. https://doi.org/10.1108/IJCHM-09-2012-0165

Legris, P., Ingham, J., \& Collerette, P. (2003). Why do people use information technology? A critical review of the technology acceptance model. Information \& Management, 40(3), 191-204. https://doi.org/10.1016/S0378-7206(01)00143-4

Little, L., Briggs, P., \& Coventry, L. (2005). Public space systems: Designing for privacy? International Journal of Human Computer Studies, 63(1-2), 254-268. https://doi.org/10.1016/j.ijhcs.2005.04.018

Luse, A., Vidrio-Baron, S. B., Mennecke, B. E., \& Townsend, A. M. (2008). A Location-based Approach for Distributed Kiosk Design A Location-based Approach for Distributed Kiosk Design. Proceedings of the Fourteenth Americas Conference on Information Systems, Toronto, ON, Canada August 14th-17th 2008. Retrieved from http://aisel.aisnet.org/amcis2008\%0Ahttp://aisel.aisnet.org/amcis2008/78

Maguire, M. C. (1999). A review of user-interface design guidelines for public information kiosk systems. International Journal of Human-Computer Studies, 50(3), 263-286. https://doi.org/10.1006/ijhc.1998.0243

Nizar, N. N. M., \& Rahmat, M. K. (2018). Examining The Museum Visitors Use Of Mobile Technology Through Technology Acceptance Model (TAM). Journal of Tourism, Hospitality and Environment Management, 3(September), 14-24.

Pallud, J. (2017). Impact of interactive technologies on stimulating learning experiences in a museum. Information and Management, 54(4), 465-478. https://doi.org/10.1016/j.im.2016.10.004

Parikh, S. P., \& Esposito, J. M. (2012). Negative feedback for small capacitive touchscreen interfaces: A usability study for data entry tasks. IEEE Transactions on Haptics, 5(1), 39-47. https://doi.org/10.1109/TOH.2011.71

Prensky, M. (2001a). Digital Natives, Digital Immigrants Part 1. On the Horizon, 9(5), 1-6. https://doi.org/10.1108/10748120110424816

Prensky, M. (2001b). Digital Natives, Digital Immigrants Part 2: Do They Really Think Differently? On the Horizon, 9(6), 1-6. https://doi.org/10.1108/10748120110424843

Robandi, B., Kurniati, E., \& Sari, P. R. (2019). Pedagogy In The Era Of Industrial Revolution 4.0. Advances in Social Science, Education and Humanities Research, 239, 38-46. https://doi.org/10.2991/upiupsi-18.2019.7

Saidin, A. Z., Alwi, A., \& Shaari, N. (2018). Muzium Padi Kiosk: A Case Study in Muzium Padi Kedah. Indian Journal of Arts, 8, 74-78.

Salleh, N. H. (2015). Mixed Methods Approach For The Study of Fire Safety Management in Malaysia Heritage Building. In N. A. M. Ariffin, M. M. Rashid, \& N. H. Salleh (Eds.), Methodologies in Architectural Research (1st ed., pp. 19-30). Kuala Lumpur: IIUM Press.

Sears, A. (1991). Improving touchscreen keyboards: Design issues and a comparison with other devices. Interacting with Computers, 3(3), 253-269. https://doi.org/10.1016/09535438(91)90016-U

Serrell, B. (1997). Paying Attention: The Duration and Allocation of Visitors' Time in Museum 
INTERNATIONAL JOURNAL OF ACADEMIC RESEARCH IN BUSINESS AND SOCIAL SCIENCES

Vol. 10, No. 9, 2020, E-ISSN: 2222-6990 @ 2020 HRMARS

Exhibitions. Curator: The Museum Journal, 40(2), 108-125. https://doi.org/10.1111/j.21516952.1997.tb01292.x

Shin, G., \& Zhu, X. (2011). User discomfort, work posture and muscle activity while using a touchscreen in a desktop PC setting. Ergonomics, 54(8), 733-744.

https://doi.org/10.1080/00140139.2011.592604

Taha, D. D. A. H. (2008). Museums in Malaysia : In Technology.

Thong, J. Y. L., Hong, W., \& Tam, K. Y. (2002). Understanding user acceptance of digital libraries: What are the roles of interface characteristics, organizational context, and individual differences? International Journal of Human Computer Studies, 57(3), 215-242. https://doi.org/10.1016/S1071-5819(02)91024-4

Wang, Y. S., \& Shih, Y. W. (2009). Why do people use information kiosks? A validation of the Unified Theory of Acceptance and Use of Technology. Government Information Quarterly, 26(1), 158165. https://doi.org/10.1016/j.giq.2008.07.001

Zenios, M., \& Ioannou, E. (2018). Digital Natives and Digital Immigrants Revisited: A Case of CALL. Lecture Notes in Computer Science (Including Subseries Lecture Notes in Artificial Intelligence and Lecture Notes in Bioinformatics), 10925 LNCS, 99-110. https://doi.org/10.1007/978-3-31991152-6_8 